\title{
New Diatomite Filler for Improvement of Paper Strength Properties
}

\author{
WEI SHANG*, HAORAN HAN, HUNAN LIANG \\ College of Chemistry Engineering, Northeast Electric Power University, Jilin 132012, China
}

\begin{abstract}
In this work, diatomite particles were modified to improve the bondability of diatomite particles with pulp fibers and filler retention via a complex of cationic starch-sodium hexametaphosphate coating method. The particle size, FTIR spectroscopy characteristic and morphology of the resulting modified diatomite were studied to confirm the successful modification. The SEM results illustrated that the surface of modified diatomite particles was covered by the complex coatings. The coating efficiency of the complex of cationic starch-sodium hexametaphosphate on diatomite surface was up to 98\%. Compared with the handsheet filled unmodified diatomite, the handsheet filled with modified diatomite had higher strength properties and lower bulk. When cationic starch dosage was $7 \%$, and filler dosage was $25 \%$, the resulting tensile strength of filled modified diatomite handsheet was 22.1\% higher than the handsheet filled unmodified diatomite. Furthermore, with the filler loading of $30 \%$, compared with that of unmodified diatomite, filler retention of modified diatomite was increased by 20.4\%. The larger particle size and higher zeta potential of modified diatomite were benefitial to increase retention of modified diatomite filler.
\end{abstract}

Keywords: cationic starch, diatomite, filler modification, retention improvement, strength improvement

\section{Introduction}

It has been a long history that mineral fillers are used in paper industry [1-3]. Many kinds of mineral fillers have been used, such as kaolin, calcium carbonate, diatomite, talcum powder and titanium dioxide [4-7]. Fibers are the most important component of paper. The second important component of the paper is mineral filler. The people always hope increase the filler ratio in paper to improve the cost competitiveness of paper products [8-12]. However, the use of filler has negative impact on the strength properties of the paper, especially at high filler addition level. One of the prominent problems in the use of filler is that many strength properties (such as tensile index , tear index ) of paper were usually decreased with the increase of filler addition level [13-15]. Because of the above mentioned adverse effects, researchers have developed some techniques to overcome these shortcomings $[13,16-20]$. According to the different uses of paper, we can use a variety of methods to modify the filler (for example, chemical modification, physical modification and surface modification, etc.,) for acquiring the requirements of different paper and ultimately to improve the performance of the paper. [21-25]. In recent years, the surface modification of filler for improving the hydrogen bonding between fibers has been paying more and more attention [26-30].

Chemical structure of starch is similar to cellulose, and thereby starch is suitable for the surface modification of papermaking filler. Starch can be attached on the surface of filler to improve the bondability between fillers and fibers. It was found that adding modified filler can not only increase the retention rate of the filler, but also could increase the performance of the products while maintaining other indexes [31-36]. Diatomite is a kind of non-toxic, harmless and very environmentally friendly mineral material. Diatomite has been used in many fields. As a novel papermaking filler, diatomite has attracted more and more attention [37-40]. Compared with other fillers, diatomite has many excellent characteristics, such as small density, non-toxic, stable chemical properties, and more pores [41-55]. [12,56-59]. It is very meaningful and important to study whether can use cationic starch and sodium hexametaphosphate to modify diatomite for improving the strength properties of paper [60-67].

\footnotetext{
*email:w.shang71@yahoo.com,sw-d@163.com
} 
In this work, diatomite particles were modified with cationic starch and sodium hexametaphosphate by coating method. The basic characteristics of modified diatomite particles including particle size, coating efficiency, FTIR spectroscopy characteristic, Zeta potential and surface morphology were evaluated. Meanwhile, the effect of modified diatomite filler on handsheet strength properties and filler retention was investigated.

\section{Materials and methods}

\subsection{Materials}

Diatomite was obtained from Hongyuan Co., Ltd. (Jilin, China). Cationic starch was purchased from Kang pu hui wei Co., Ltd. (Beijin, China). Sodium hexametaphosphate (SHP) was obtained from Aladdin Co., Ltd. (Shanghai, China). CPAM (Cationic polyacrylamide) was obtained from BASF Co., Ltd (China). APMP pulp board was obtained from a mill (Mudanjiang, China). The pulp was beaten in a Valley beater and the pulp was beaten to $45^{\circ} \mathrm{SR}$ for use.

\subsection{Methods}

\subsubsection{Preparation of Cationic Starch-Sodium Hexametaphosphate Complex Modified Diatomite}

Diatomite particles were coated with cationic starch-sodium hexametaphosphate. This is a method of coating modification. The specific modification process was as follows: $3 \mathrm{wt} \%$ cationic starch (the degree of substitution of cationic starch was 0.05 ) suspension was prepared, the cationic starch suspension was cooked at $90{ }^{\circ} \mathrm{C}$ for $1 \mathrm{~h}$. Dry diatomite particles $\left(10 \times 10^{4} \mathrm{mg}\right)$ were added to a $1 \mathrm{~L}$ beaker, and then a certain amount of deionized water was added to the beaker, to form the final concentration of diatomite slurry was $15 \times 10^{4} \mathrm{mg} / \mathrm{L}$. The diatomite slurry was stirred by mixing with a stirrer for $10 \mathrm{~min}$, and then the diatomite slurry was added into the above cationic starch suspension and stirred for a quarter of an hour to form the mixture. Sequentially, $3 \mathrm{wt} \%$ sodium hexametaphosphate suspension was putted into the above mixture and stirred for a quarter of an hour and stood at $20{ }^{\circ} \mathrm{C}$ for two days. The supernatant of the above mixture was collected to measure the total organic carbon (TOC), and the sediment was washed by water until neutral. Finally, the sediment was dried at $85{ }^{\circ} \mathrm{C}$ for about $3 \mathrm{~h}$. The cationic starch-sodium hexametaphosphate modified diatomite was gotten. The complex of cationic starch-sodium hexametaphosphate modified diatomite samples with different cationic starch/diatomite ratios were obtained by the above preparation procedure [6872].

\subsubsection{Characterization of Modified Diatomite Filler}

The morphology characteristics of modified diatomite and unmodified diatomite were observed by SEM (SM6510A). The coating efficiency (CTEY, \%) of the complex of starch-fatty acid on diatomite surface was evaluated by the content of the total organic carbon (TOC) in the supernatant evaluated by a TOC analyzer (Liqui TOC). CTEY was calculated by the following formula:

$$
\operatorname{CTEY}(\%)=\left[\left(W_{i}-W_{d}\right) / W_{i}\right] \times 100
$$

where, $W_{i}$ and $W_{d}(\mathrm{~g})$ are the weights of the initial cationic starch-sodium hexametaphosphate complex and the cationic starch-sodium hexametaphosphate complex dissolved in the supernatant, respectively.

Malvern Zetasizer-3000 was used to measure the Zeta potential of modified diatomite and unmodified diatomite filler. OMEC LS-POP particle size analyzer was used to detect the particle size of diatomite filler. Using IRAffinity-1 FTIR spectrophotometer to test the FTIR spectrum of diatomite filler [72-80].

\subsubsection{Handsheets Preparation and Test of Physical Properties}

Bleached hardwood kraft pulp suspension (1\%) were prepared, and then various dosages of diatomite filler were added into the pulp suspension and $0.5 \mathrm{wt} \%$ of cationic polyacrylamide were also added into the pulp suspension, let the mixer continue to stir until the mixture is absolutely mixed well. The handsheet was prepared with a Rapid-Koethen handsheet former. Grammage of the handsheets 
were $60 \mathrm{~g} \cdot \mathrm{m}-2$. All handsheets were prepared at $105^{\circ} \mathrm{C}$ drying temperature, $1.0 \mathrm{MPa}$ pressure and the dried time was 10 minutes. The handsheets were then conditioned for $24 \mathrm{~h}(50 \pm 2 \%$ relative humidity, $23 \pm 1{ }^{\circ} \mathrm{C}$ ). Physical properties of the handsheet was tested according to TAPPI Test Methods.

\subsubsection{Measure of Filler Retention in Handsheets}

The filler content in handsheets was tested by ashing in a muffle furnace $\left(575 \pm 25{ }^{\circ} \mathrm{C}, 6 \mathrm{~h}\right)$. The filler retention $(F R, \%)$ was measured. The formula as follow (eq b):

$$
F R(\%)=\left[M_{1} /\left(D \times M_{2}\right)\right] \times 100
$$

where, $M_{1}(\mathrm{~g})$ is the weight of ash in handsheets, and $M_{2}(\mathrm{~g})$ is the weight of the filler added. D is the weight fraction of diatomite in filler.

Error Analysis: All the data were tested multiple measurements (3-8 runs) and a average value was reported. The error margin as follows: particle size $( \pm 3.5 \%)$, Zeta potential $( \pm 0.6 \%)$, filler retention $( \pm 0.5 \%)$, physical properties $( \pm 6 \%)$.

\section{Results and discussions}

\subsection{Forming Mechanism and Characterization of Modified Diatomite}

In the process of modified diatomite, researchers pay more and more attention to modifier renewable and environmental protection. Therefore, in this research, we chose the renewable of cationic starch and sodium hexametaphosphate as the modifying agent to coat surface of diatomite particles, because of cationic starch molecules contain a lot of hydroxyl groups. The hydroxyl groups can be form a hydrogen bond between the fibers. The schematic diagram was shown in Figure 1.

From figure 1, it could seen the whole modification process. Firstly, cationic starch adsorbed to the diatomite particles surface by adsorption. Secondly, diatomite particles had adsorbed cationic starch interact with sodium hexametaphosphate, because of the cationic starch and sodium hexametaphosphate can form complex (CSSC). Finally, diatomite particles were coated by CSSC. It is worth noting that in the whole process of modification, the control of various technological parameters is particularly important, such as cationic starch dosage, sodium hexametaphosphate dosage and surface charge of modified diatomite. These parameters directly determine the modification effect.

To understand the modification mechanism, we need to fully understand the material properties of diatomite. The surface of the diatomite particles also have a lot of hydroxyl groups, but because of its chemical inert itself. It makes difficult to react with fiber surface hydroxyl hydrogen and form the hydrogen bond. Therefore, we through the introduction of cationic starch in diatomite particles surface to increase the number of hydroxyl groups. The structure of cationic starch and cellulose are similar, so it is easy to form hydrogen bond between the hydroxyl. Therefore, the binding ability between diatomite particles and fibers can be improved.

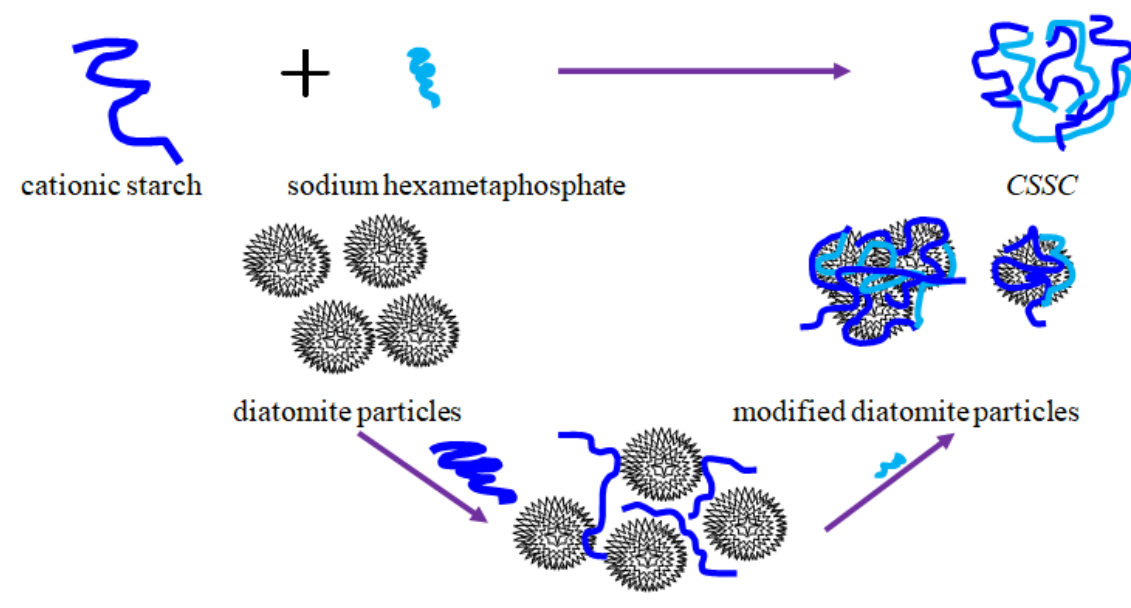

Figure 1. Preparation of modified diatomite using cationic starch and sodium hexametaphosphate 
The SEM image of unmodified diatomite particles is shown in Figure 2a and the SEM image of modified diatomite particles is shown in Figure $2 b$. It was found that a significant difference between Figures $2 \mathrm{a}$ and $2 \mathrm{~b}$. It was also explained that diatomite particles were successfully coated with cationic starch-sodium hexametaphosphate complex. It is shown in Figure $2 \mathrm{a}$ that the image of unmodified diatomite retained its original morphology. From the Figure $2 b$, we can saw that the modified diatomite particles were coated with a layer of complex .The surface of modified diatomite was fully covered and the micropores were invisible, which illustrated that diatomite was modified by the cationic starch-sodium hexametaphosphate complex. Since cationic starch has many hydroxyl groups in the molecular chain, the bondability of modified diatomite particles with fibers was enhanced. SEM images of modified diatomite particles show that the combination of cationic starch and sodium hexametaphosphate can effectively modify diatomite and make diatomite particles aggregate (Figure $2 \mathrm{~b}$ ), possibly due to the bridging function of the cationic starch-sodium hexametaphosphate complex. This aggregation phenomenon was beneficial to improve filler retention because of the larger size of composites/aggregates compared with the unmodified diatomite particles.

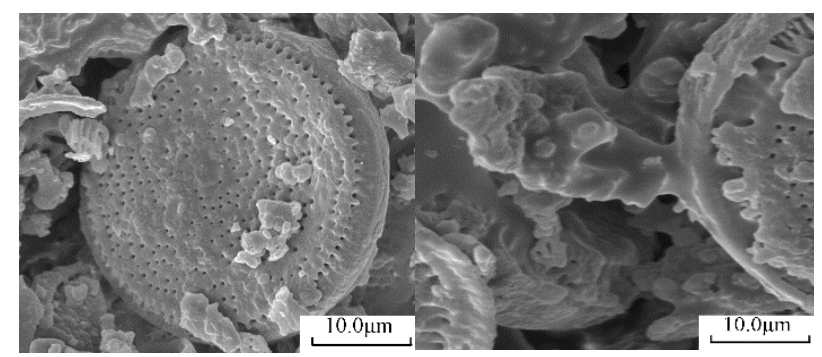

(a)

Figure 2. SEM images of unmodified (a) and modified (b) diatomite fillers.

For modified diatomite, it is very important to effectively utilize cationic starch-sodium hexametaphosphate complex. If the utilization efficiency of cationic starch-sodium hexametaphosphate complex is low, a good coating could not be formed on the surface of diatomite. In this research, the CTEY of cationic starch-sodium hexametaphosphate complex on the surface of diatomite was measured, and the results are shown in Table 1.

Table 1. CTEY of cationic starch-sodium hexametaphosphate complex on the surface of diatomite.

\begin{tabular}{ccc}
\hline & & $C T E Y(\%)$ \\
sample no. & Sodium hexametaphosphate dosage $(\%)$ & \\
\hline 1 & 3 & 98.13 \\
\hline 2 & 4 & 98.17 \\
\hline 3 & 5 & 98.29 \\
\hline 4 & 6 & 98.40 \\
\hline 5 & 7 & 98.43 \\
\hline
\end{tabular}

It was found that the $C T E Y$ of cationic starch-sodium hexametaphosphate complex on the surface of diatomite were all more than $98 \%$. It indicated that cationic starch-sodium hexametaphosphate complex could be effectively coated on the surface of diatomite under the experimental conditions. Sodium hexametaphosphate dosage had almost no effect on CTEY, which illustrated that $3 \%$ sodium hexametaphosphate was enough.

The zeta potential of diatomite particles was tested, in order to estimate the change of diatomite particles charge and observe the impact the filler retention and flocculation of diatomite filler on fibers. It is important a factor that the Zeta potential of diatomite particles are affect application performance of diatomite filler in pulp fibers networks. In this work, the Zeta potentials of unmodified and cationic starch-sodium hexametaphosphate complex modified diatomite fillers with different dosages of 
cationic starch were measured. Table 2 illustrates the influence of cationic starch dosage on the zeta potential of diatomite particles.

Table 2. Zeta potential of cationic starch-sodium hexametaphosphate complex modified diatomite filler

\begin{tabular}{ccc}
\hline sample no. & cationic starch dosage $(\%)$ & Zeta potential $(\mathrm{mV})$ \\
\hline 1 & 0 (unmodified diatomite) & -63.12 \\
\hline 2 & 3 & -25.31 \\
\hline 3 & 5 & -15.22 \\
\hline 4 & 7 & 1.29 \\
\hline 5 & 9 & 10.21 \\
\hline 6 & 11 & 13.12 \\
\hline
\end{tabular}

The electropositive of modified diatomite particles were enhanced compared with unmodified diatomite particles $(-63.12 \mathrm{mV})$. Furthermore, the Zeta potential enhanced with the enhance cationic starch use level. The low cationic starch dosage modified diatomite particles were less positively charged than that of the other cationic starch dosage. The Zeta potential of modified diatomite particles had become to positive when the cationic starch dosage was $7 \%$. The Zeta potential of modified diatomite was $1.29 \mathrm{mV}$. It is primarily because that cationic starch can contribute significantly to improve the Zeta potential of the modified diatomite. Consequently, the introduction of cationic starch-sodium hexametaphosphate complex coated the diatomite particles surface, it is advantageous to increase the Zeta potential.

The particle sizes of unmodified and modified diatomite are both presented in Figure 3. Filler particle size is very important because it affects paper physical properties and filler retention. From Figure 3, it could seen that the unmodified diatomite average particle size was $4.81 \mu \mathrm{m}$. The modified diatomite average particle size was larger than unmodified diatomite. the modified diatomite average particle size was significantly increased to $6.28-7.61 \mu \mathrm{m}$ after modification. The particle size of modified diatomite became larger compared with unmodified diatomite particles. It was probably because that cationic starch-sodium hexametaphosphate complex caused multiple diatomite particles to clump together. The process of coating and aggregation of diatomite particles was shown in Figure 1. The cationic starch-sodium hexametaphosphate was able to coat one single diatomite particle or several diatomite particles. The increase of Zeta potential and particle size of diatomite was helpful to improve the performance of diatomite.

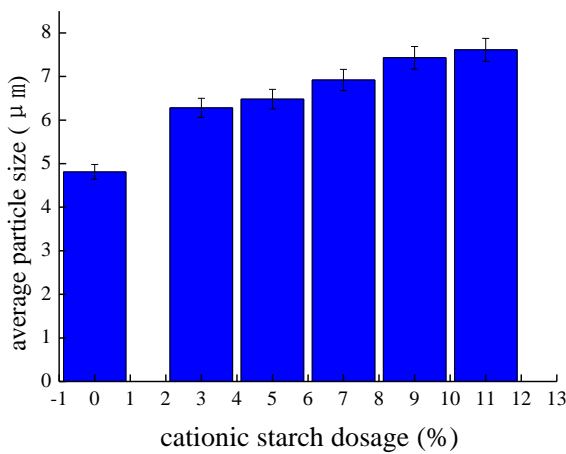

Figure 3. Effect of cationic starch on the particle size of diatomite

As Figure 4 shown, the characteristic peak at $1082 \mathrm{~cm}^{-1}$ is attributed to Si-O stretching vibration and the characteristic peak is the main characteristic peak of unmodified diatomite. The peak at 751 $\mathrm{cm}^{-1}$ is belong to $\mathrm{Si}-\mathrm{O}-\mathrm{Si}$ stretching vibration. The peak at $510 \mathrm{~cm}^{-1}$ is attributed to $\mathrm{Si}-\mathrm{O}-\mathrm{Si}$. Compared with unmodified diatomite, modified diatomite shows a lot of new characteristic peaks. New characteristic peak appears at $3250 \mathrm{~cm}^{-1}$ belonging to the ${ }^{-} \mathrm{OH}$ characteristic peak. The peak at 1075.8 
$\mathrm{cm}^{-1}$ is attributed to $\mathrm{C6}-\mathrm{O}-\mathrm{H}$ stretching vibration of cationic starch molecular chain. This indicated that cationic starch had incorporated into diatomite. The peaks at $1151.7 \mathrm{~cm}^{-1}$ is $\mathrm{P}=\mathrm{O}$ vibration peak and the peaks at $1284.6 \mathrm{~cm}^{-1}$ is $\mathrm{P}-\mathrm{O}-\mathrm{C}$ vibration peak. These characteristic peaks proved that cationic starch and sodium hexametaphosphate had been crosslinked, and the starch-sodium hexametaphosphate complex had coated on the surface of diatomite particles. It was also proved that the cationic starch basic chemical structure did not damage. So can provides the guarantee for the modified diatomite application in papermaking.

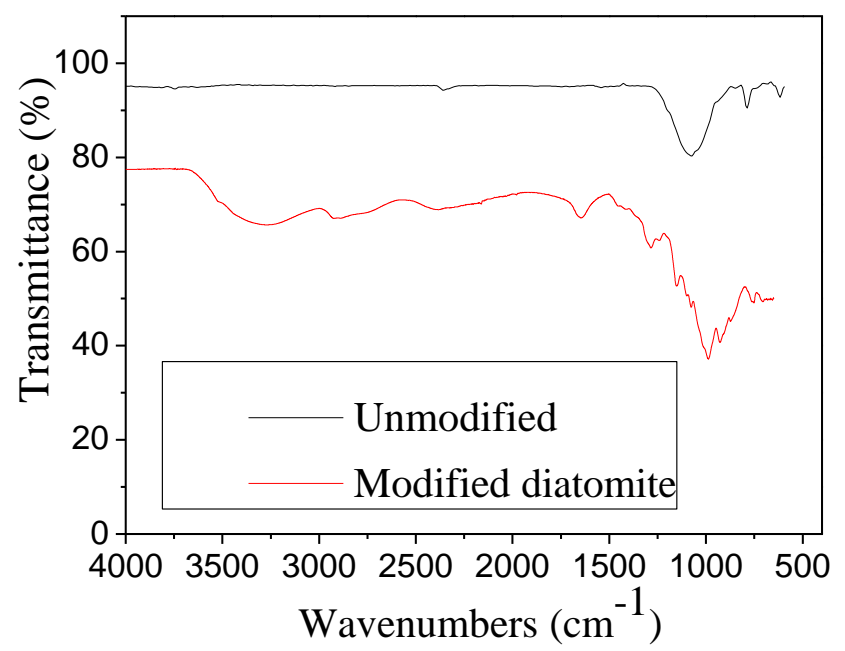

Figure 4. FTIR spectra of unmodified and modified diatomite fillers

\subsection{Impact of Modified Diatomite on Filler Retention}

The filler retention rate was a very important index in papermaking. The cationic starch-sodium hexametaphosphate modified diatomite fillers retention with different dosages of cationic starch were measured. The effect of cationic starch to the filler retention is shown in Figure 5a. The fillers retention of modified diatomite increased with increasing cationic starch dosage (the filler dosage was $30 \%$ ). The modified diatomite retention was higher than $88 \%$ when cationic starch dosage was $7 \%$. However, The fillers retention of modified diatomite increased slightly although the cationic starch dosage continued to improve when cationic starch dosage was over $7 \%$.

Figure $5 \mathrm{~b}$ illustrates that the filler retention rate of modified diatomite filler (cationic starch dosage was 7\%) was higher than unmodified diatomite filler. The filler retention rate of the unmodified diatomite filled handsheet was lower than that of the modified diatomite filled handsheet. At a filler loading of $30 \%$, the modified diatomite retention was higher than $88 \%$. However, the retention rate of unmodified diatomite filler was under $74 \%$. In this case, the cationic starch-sodium hexametaphosphate modification was benefitial to increase filler retention. It was mainly because that the cationic starch-sodium hexametaphosphate coated diatomite particles formed small aggregates (6.28$7.21 \mu \mathrm{m})$ rather than individual particles. Moreover, the zeta potential of modified diatomite particles were increased, which was beneficial to enhancing the retention. The increased zeta potential by adding cationic retention agent, the zeta potential of diatomite filler surface can be improved, and the retention of filler between fibers can be improved. 


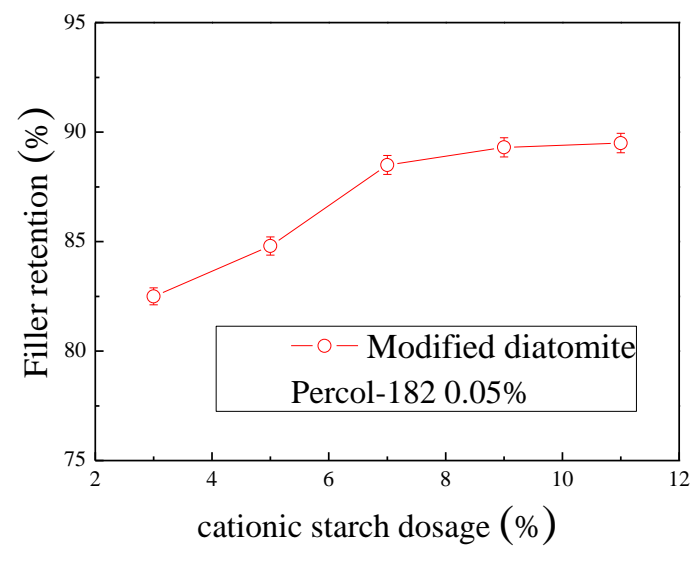

a

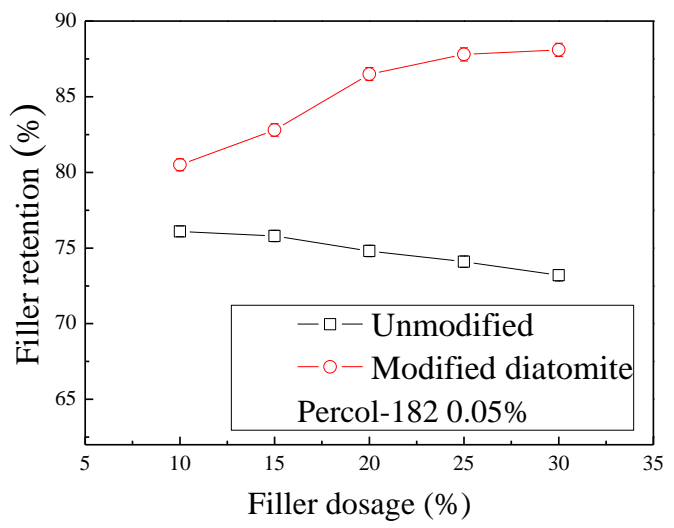

$\mathrm{b}$

Figure 5. Effect of cationic starch dosage on filler retention(a) and filler dosage on the filler retention $(b)$

\subsection{Strength Properties of Modified Diatomite Filled Handsheet}

As shown in Figure 6. It is illustrated that the effect of the modified diatomite dosage and unmodified diatomite dosage on physical properties. The results shown that the strength properties of the handsheets became lower and lower when the dosage of fillers increased. It can be seen that the strength properties of the handsheets filled with unmodified diatomite decreased more and faster. It was mainly because that the dosage of unmodified diatomite filler increased which leaded to the decrease the bonding opportunities between the fibers. However, the unmodified diatomite filler particles couldn't effectively combine with the fibers. In addition, when the modified diatomite filler dosage were increased. The modified diatomite itself will be scattered unevenly. Fiber compound together by bridge connection of modified diatomite filler gets decreased.

The connection opportunity of the fibers each other gets decreased. However, the strength properties of the handsheets using modified diatomite were higher when the same filler content. Especially for high dosage cationic starch as modifier, with the filler dosage improved, the tensile strength of modified diatomite filled handsheets increased by 19 and $69 \%$ compared with unmodified diatomite filled paper when the dosage of diatomite filler was improved from 10 to $30 \%$. It is mainly because that the modified diatomite was coated with cationic starch-sodium hexametaphosphate complex. The modified diatomite has rich hydroxy groups. Therefore, The hydroxyl groups on the surface of modified diatomite particles could form hydrogen bond with the fibers. Moreover, filler and pulp fiber would be more tightly bound due to the coating of cationic starch-sodium hexametaphosphate complex. Therefore, the tensile strength of the handsheet filled with modified diatomite was effectively improved.

As shown in Figure 6, the bulk of handsheet was also investigated. The bulk of handsheet increased with the increase of filler addition level. Meanwhile, the bulk of modified diatomite filled handsheet was lower than that of unmodified diatomite filled handsheet. It indicated that the cationic starchsodium hexametaphosphate complex coatings on the surface of diatomite could improve the bondability of diatomite particles with pulp fibers. All the above results indicated that cationic starchsodium hexametaphosphate complex modified diatomite can improve the strength properties of filled handsheet.

Nowadays, there are more and more diatomite modification methods. In this work, diatomite particles were modified with cationic starch and sodium hexametaphosphate by coating method. Compared with the unmodified diatomite, the modified diatomite can effectively improved the filler retention, strength strength properties of modified diatomite filled handsheet [70-85]. 

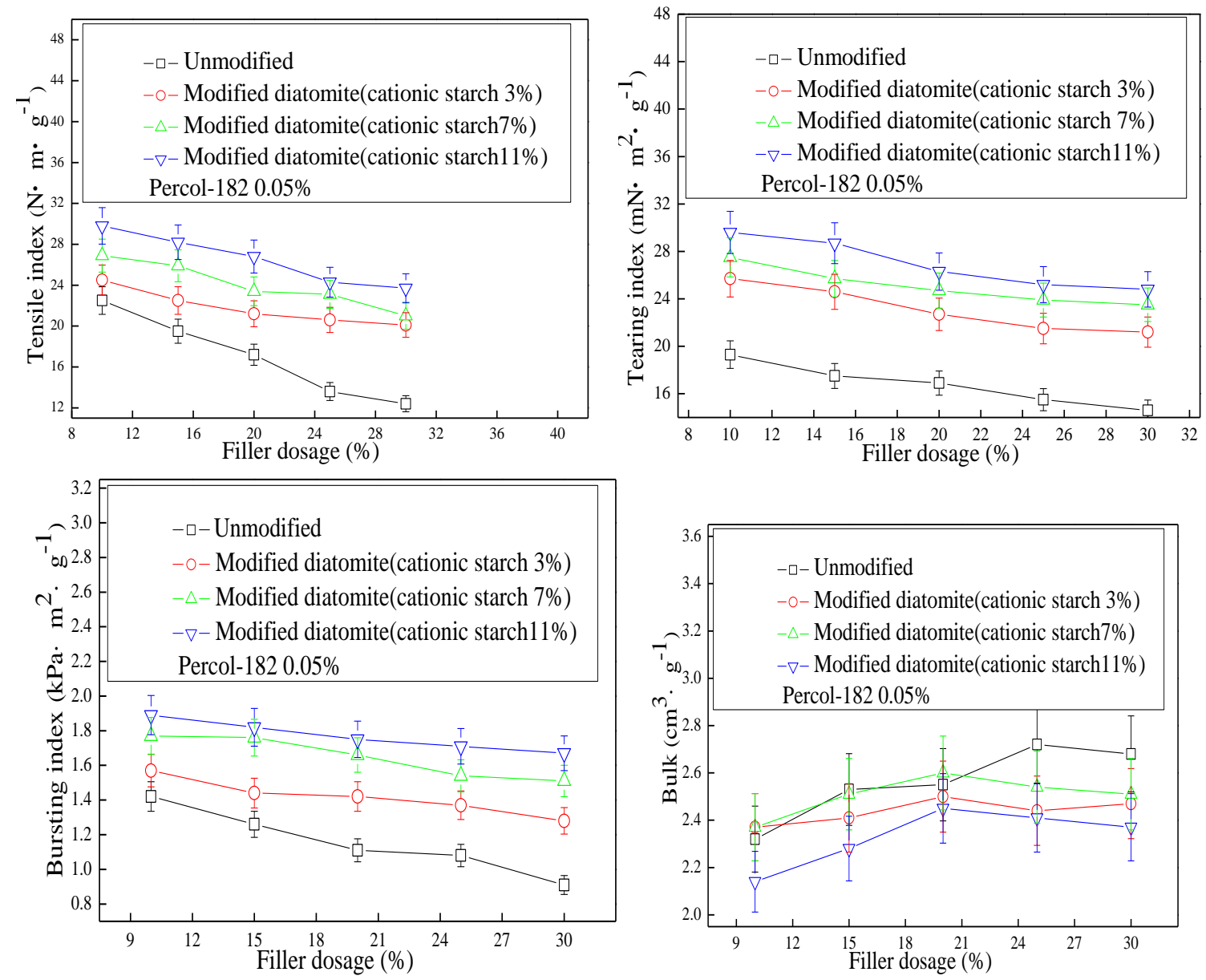

Figure 6. Effect of filler dosage on physical properties of filled handsheet

\section{Conclusions}

In this study, cationic starch and sodium hexametaphosphate were proved to be effective modifiers in the modification of diatomite. The utilization efficiency of cationic starch-sodium hexametaphosphate complex is high a good coating could be formed on the surface of diatomite. The coating efficiency (CTEC) was high as $98 \%$. The SEM observations and particle size analysis confirmed the formation of modified diatomite filler. Compared with unmodified diatomite, Zeta potential of modified diatomite could be effectively raised, and it could change to electropositive. Modified diatomite effectively enhanced the retention of the diatomite filler. The physical properties of paper were significantly improved. As to high dosage cationic starch unmodified diatomite filled paper, at the filler content of $25 \%$, the tensile strength is $22.1 \%$ lower than that of modified diatomite filler paper.

Acknowledgements: This work was financially supported from doctoral research foundation of northeast electric power university (Grant no. BXJXM-2018216) and the science and technology development project of Jilin Province education department (Grant no. 201684).

\section{References}

1.SEYED, P., HASAN, M. AHMAD, J., Airborne toluene degradation by using manganese oxide supported on a modified natural diatomite. J. Porous Mater., 23(4), 2016, 1015-1024.

2.MERADI, H., ATOUIL, B. L., LABIOD, K. ISMAIL, F., Characterization of diatomite from Sig region (West Algeria) for industrial application. Mange. Environ. Qual., 27(3), 2016, 281-288. 
3.DONG, G. R., ZHANG, Y., Diatomite Modification and its Adsorption of Heavy Metal Ions. Environ. Engin., 4, 2014, 664-667.

4.SHENG, W., LING, H. SHEN, R., Removal of Terephthalic Acid from Waste Water Using Diatomite Adsorbent, Mater. Sci. Forum., 787, 2014, 82-91.

5.ChEN, M., WANG, J., YANG, Q., XIA, L., An Improved Topological Hybrid Passivity Control for UPQC. J. North. Electr. Power. Univ., 39(06), 2019,78-84.

6.HA, J., LEE, J. SONG, I., The preparation and characterizations of the diatomite-kaolin composite support layer for microfiltration. J. Ceram. Soc. Jpn., 123(1440), 2015, 656-661.

7.HUAN, W., TIAN, M., WANG, Z, YANG, Y., Adsorption of Enzyme on Modified Diatomite by Organo-Functional Group and Metallic Ions. Appl. Mech. Mater., 618, 2014, 321-325.

8.DONG, G., SU, Z. WANG, J., Diatomite modification and its application in wastewater treatment. Adv. Appl. Sci. Manuf., 850, 2014, 1355-1359.

9.SHI, Y., ZHANG, S. WANG, J., The Research Progress of Sacrificial Anode Materials. J. North. Electr. Power. Univ., 37(4), 2017, 80-85.

10.REN, Z., GAO, H., GUAN, J. LIU, X., Preparation Processes of Filter Aids Using Diatomite Concentrate. Appl. Mech. Mater., 312, 2013, 323-327.

11.RAO, Z., ZHANG, G., XU, T HONG, K., Experimental study on a novel form-stable phase change materials based on diatomite for solar energy storage. Sol. Energy Mater. Sol. Cells., 182, 2018, 52-60. 12.JIN, Y., WANG, C., HUANG, B., SONG, Q. JIN, X., Characteristic and Application Progress of Diatomite. Bull. Chinese. Ceramic. Soci., 35(3), 2016, 810-814.

13.ZHAO, G., JIANG, T. SHI, J., The Research Progress of Polyoxometalate-functionalized Energy Storage Materials. J. North. Electr. Power. Univ., 37(3), 2017, 73-82.

14.LI, Z., KAIGE, M., HUAN, L., XUE, J., LI, J. LI, L., Preparation of Diatomite-Based Porous Ceramics. Adv. Energ. Environ. Mater., 2017, 355-361.

15.CHEN, R., ZHOU, L., HAO, D., CUI, D., Migrationand Adsorption Characteristics of Heavy Metal $\mathrm{Pb}^{2+}$ in the Sand. J. North. Electr. Power. Univ., 39(04), 2019, 54-60.

16.WENG, J., QIU, R. CHEN, L., Composite Paper Sheet Containing $\mathrm{TiO}_{2}$-diatomite for Removing Phenol in Aqueous Solution. Bioresources., 12(3), 2017, 5057-5070.

17.XU, G., LENG, G., YANG, C., QIN, Y., WU, Y., CHEN, H., CONG, L. DING, Y., Sodium nitrate-Diatomite composite materials for thermal energy storage. Solar. Energy., 146, 2017, 494-502. 18.WANG, Z., SONG, X., YANG, Y., WANG, D. SUN, M., Recent Progress of Research of NonEnzymatic Glucose Sensors Based on Copper. J. North. Electr. Power. Univ., 38(1), 2018, 95-100 .

19.FAN, H., QI, Y., CAI, J., RONG, Z. LIU, J., Fly ash based composite fillers modified by carbonation and the properties of filled paper. Nord. Pulp. Pap. Res. J., 32(4), 2017, 666-673.

20.QU, Z., LIU, S., Effect of Filler on the Hue of Ink-jet Base Paper. Appl. Sci. Graph. Commun. Packag., 2018, 617-622.

21.HE, M., CHO, B. WON, J., Effect of precipitated calcium carbonate-Cellulose nanofibrils composite filler on paper properties. Carbohydr. Polym., 136, 2016, 820-825.

22.PENG, Y., HE, B. ZHAO, L., The effect of pre-flocculation of lime mud by wet-end additives on paper properties. Nord. Pulp. Pap. Res. J., 30(2), 2015, 243-249.

23.ROUZBEH, A., MOHAMMADREZA, D. HOSSEIN, R., The effect of coatings and coating weight by two types of PCC on barrier and optical properties and roughness of paper. Iran. J. Wood. Paper. Indu., 8(2), 2017, 283-295.

24.LV, H., XI, L., SUN, L., BAI, R., The Preparation of the Diatomite-Loaded Solid Superacid Catalyst and its Multiphase Fenton-Like Degradation of Rhodamine B. J. North. Electr. Power. Univ., 39(04),2019, 49-53.

25.WANG, L., LI, C., PENG, J. LIU, H., A laboratory study on the use of maple CTMP and calcium carbonate fillers in fine paper production. Nord. Pulp. Pap. Res. J., 31(4), 2016, 608-612.

26.BALEA, A., BLANCO, A., MERAYO, N. NEGRO, C., Effect of nanofibrillated cellulose to reduce linting on high filler-loaded recycled papers. Appita. J., 69(2), 2016, 148-156. 
27.LIU, H., LIU, N., LU, M., LIU, P., LIANG, S., XU, D., Research Progress of Metal-organic Frameworks in the Adsorption Removal of Heavy Metal Ions From Wastewater. J. North. Electr. Power. Univ., 39(06),2019,58-66.

28.LI, T., ZHANG, M. SONG, S., Importance of preflocculated precipitated calcium carbonate (PCC) floc size on paper strength. Appita., 70(2), 2017, 133-138.

29.XU, P., LIU, Z., SUN, J., HUI, L. WANG, C., In fibre synthesis of calcium silicate for fine paper. Appita. J., 69(4), 2016, 339-343.

30.JU, Y., QIN, C., WANG, D., BAI, J., Experimental Study on Preparation of Self Compacting Reactive Powder Concrete. J. North. Electr. Power. Univ., 39(02), 2019, 68-73.

31.SHA, L., CHEN, K., Surface modification of ammonium polyphosphate-diatomaceous earth composite filler and its application in flame-retardant paper. J. Therm. Anal. Calorim., 123(1), 2016, 339-347.

32.LV, Y., ZENG, C., GONG, J., CHEN, C., Research on the Reuse Technology of Ash and Slag in Garbage Power Plant. J. North. Electr. Power. Univ., 39(04),2019, 76-80.

33.LIN, S., HAN, F., ZHANG, X., YAN, K., WANG, Q. ZHANG, K., Preparation of Rice Straw Biomass Based Carbon Microspheres Via in Situ Synthesis Method. J. North. Electr. Power. Univ., 38(2), 2018, 78-82.

34.LOUREN, A., GAMELAS, J., NUNES, T., AMARAL, J., PERÉ, M. FERREIRA, P., Influence of TEMPO-oxidised cellulose nanofibrils on the properties of filler-containing papers. Cellulose., 24(1), 2017, 349-362.

35.LI, T., FAN, J., CHEN, W., SHU, J., QIAN, X., WEI, H., WANG, Q. SHEN, J., Coaggregation of mineral filler particles and starch granules as a basis for improving filler-fiber interaction in paper production. Carbohydr. Polym., 149, 2016, 20-27.

36.QIN, H., YAO, K. ZHANG, L., Variation of Retorting Products for Dewaxed Oil Shale. J. North. Electr. Power. Univ., 38(4), 2018, 59-65.

37.ABEER, M., NIVIN, M., MOHAMED, A. MOHAMED, M., The influence of $\mathrm{TiO}_{2} / \mathrm{CC}$ core/shell pigments on the properties of paper sheets. Powder Technol., 291,2016, 437-447.

38.CHAUHAN, V., BHARDWAJ, N., Amphoteric starch preflocculated talc filler for improving composite tensile index and filler bondability of paper. Nord. Pulp. Pap. Res. J., 30(3), 2015, 436-442.

39.YANG, S., KONG, L., LIAO, L., TAO, W., YAO, L., ZHANG, X., Effect of Inorganic Carbon on Anaerobic Treatment of Coal Gasification Wastewater. J. North. Electr. Power. Univ., 37(2), 2017, 5965 .

40.HUANG, X., QIAN, X., LI, J., LOU, S. SHEN, J., Starch/rosin complexes for improving the interaction of mineral filler particles with cellulosic fibers. Carbohydr. Polym., 117, 2015, 78-82.

41.WANG, H., WANG, J., LU, H., BO, G., ZHANG, X., CAO, Y., LIU, L., ZHANG, J., ZHANG, W., Analysis of coating electrode characteristics in the process of removing pollutants from wastewater. Fresenius. Environ. Bull., 29(2), 2020, 715-721.

42.ZENG, L., CHEN, G., CHEN, H., Comparative Study on Flow-Accelerated Corrosion and Erosion-Corrosion at a $90^{\circ}$ Carbon Steel Bend. Materials, 13(7), 2020, 1780-1796.

43.GUO, J., PAN, J., GUO, J., GU, F., KUUSISTO, J., Measurement framework for assessing disruptive innovations. Technol. Forecast. Soc. Change., 139, 2019, 250-265.

44.CHENG, Y., SONG, Z., JIN, J., WANG, J., WANG, T., Experimental study on stress wave attenuation and energy dissipation of sandstone under full deformation condition. Arab. J. Geosci., 12(23), 2019, 736-749.

45.HAIBIN, L., ZHENLING, L., Recycling utilization patterns of coal mining waste in China. Resour. Conserv. Recycl., 54(12), 2010, 1331-1340.

46.CHEN, H., FAN, D., HUANG, J., HUANG, W., ZHANG, G., HUANG, L., Finite Element Analysis Model on Ultrasonic Phased Array Technique for Material Defect Time of Flight Diffraction Detection. Sci. Adv. Mater., 12(5), 2020, 665-675. 
47.WANG, H., AN, X., ZHANG, Z., Effect of advanced treatment on ammonia nitrogen contained in secondary effluent from wastewater treatment plant. Fresenius. Environ. Bull., 27(4), 2018, 20432050.

48.GU, F., GUO, J., ZHANG, W., SUMMERS, P. A., HALL, P., From waste plastics to industrial raw materials: A life cycle assessment of mechanical plastic recycling practice based on a real-world case study. Sci. Total. Environ., 601, 2017, 1192-1207.

49.LIU, Z., FENG, J., WANG, J., Resource-Constrained Innovation Method for Sustainability: Application of Morphological Analysis and TRIZ Inventive Principles. Sustainability, 12(3), 2020, 917-939.

50.WANG, M., ZHANG, D., CHENG, Y., TAN, S. K., Assessing performance of porous pavements and bioretention cells for stormwater management in response to probable climatic changes. $J$. Environ. Manage., 243, 2019, 157-167.

51.CAO, Y., LI, Y., ZHANG, G., JERMSITTIPARSERT, K., NASSERI, M., An efficient terminal voltage control for PEMFC based on an improved version of whale optimization algorithm. Energy Reports, 6, 2020, 530-542.

52.WANG, H., ZHONG, H., BO, G., Existing forms and changes of nitrogen inside of horizontal subsurface constructed wetlands. Environ. Sci. Poll. Res., 25(1), 2018, 771-781.

53.QUAN, Q., HAO, Z., XIFENG, H., JINGCHUN, L., Research on water temperature prediction based on improved support vector regression. Neur. Comp. App., 2020, 1-10.

54.LIU, Y. X., YANG, C. N., SUN, Q. D., WU, S. Y., LIN, S. S., CHOU, Y. S., Enhanced embedding capacity for the SMSD-based data-hiding method. Signal Processing: Image. Commun., 78, 2019, 216-222.

55.CAO, Y., WANG, Q., FAN, Q., NOJAVAN, S., JERMSITTIPARSERT, K., Risk-constrained stochastic power procurement of storage-based large electricity consumer. J. Energy. Stor., 28, 2020, 101183-101192.

56.XU, Z., ZHENG, W. WANG, J., Experimental Study on the Mixed Fouling Characteristics of Microorganisms and Particles in a Tube. J. North. Electr. Power. Univ., 37(5), 2017, 44-50.

57.PAVLENKO, V., CHERKASHINA, N. PAVLENKO, Z., Synthesis of nanodispersed filler for polymer composite materials of thermostatic purpose. Nanotehnologii v Stroitel'stve, 8(5), 2016, 158174.

58.OTTESEN, V., SYVERUD, K. AND GREGERSEN, W., Mixing of cellulose nanofibrils and individual furnish components: Effects on paper properties and structure. Nord. Pulp. Paper. Res. J., 31(3), 2016, 441-447.

59.CHENG, Y., LIU, T., QIN, L., Experimental Study on the Mixture Ratio of Recycled Concrete Load-Baring Blocks. J. North. Electr. Power. Univ., 39(05), 2019, 79-85.

60.Khaldi, K., Hadjel, M. and Benyoucef, A., Removal of Quinmerac by Diatomite and Modified Diatomite from Aqueous Solution. Surf. Eng. Appl. Elect., 54(2), 2018, 194-202.

61.LIU, Y., ZHOU, J., Progress on Preparation of Antimony Sulfide Nanomaterials and Their Applications. J. North. Electr. Power. Univ., 38(1), 2018, 82-87.

62.ZHANG, Q., XIE, J., CHEN, J.H., CHENG, W., Separation of azodicarbonamide from surface of diatomite by froth flotation. J. Cent. South. Univ., 25(1), 2018, 29-37.

63.ZHENG, J., WANG, J. XU, S., Numerical Simulation of Particles Agglomerate in Turbulent Aggregation Device. J. North. Electr. Power. Univ., 37(4), 2017, 52-55.

64.JIN, Y., WANG, C., HUANG, B., SONG, Q. JIN, X., Characteristic and Application Progress of Diatomite. Bull. Chinese. Ceram. Soci., 35(3), 2016, 810-814.

65.ZHANG, L., MA, K., LUO, H., JIN, X., LI, J. LI, L., Preparation of Diatomite-Based Porous Ceramics. Adv. Energ. Environ. Mater., 2018, 355-361.

66.ZHENG, J., WANG Z., Numerical Simulation of Acoustic Agglomeration Process of Coal Fired Fine Particles. J. North. Electr. Power. Univ., 39(05), 2019, 65-71.

67.LI, L., ZHANG, M., SONG, S., YANG, B., WU, Y. YANG, Q., Preparation of core/shell 
structured silicate composite filler and its reinforcing property. Powder Technol., 332, 2018, 27-32. 68.LEI, Z., GAO, H., CHANG, X., ZHANG, L., WEN, X., WANG, Y., An application of green surfactant synergistically metal supported cordierite catalyst in denitration of Selective Catalytic Oxidation. J. Clean. Prod., 249, 2020, 1-26.

69.WANG, P., LI, J. B., BAI, F. W., LIU, D. Y., XU, C., ZHAO, L., WANG, Z. F., Experimental and theoretical evaluation on the thermal performance of a windowed volumetric solar receiver. Energy, 119, 2017, 652-661.

70.YU, D., ZHU, H., HAN, W., HOLBURN, D., Dynamic multi agent-based management and load frequency control of PV/Fuel cell/wind turbine/CHP in autonomous microgrid system. Energy, 173, 2019, 554-568.

71.WANG, Y., CAO, L., HU, P., LI, B., LI, Y., Model establishment and performance evaluation of a modified regenerative system for a $660 \mathrm{mw}$ supercritical unit running at the IPT-setting mode. Energy, 179, 2019, 890-915.

72.CAO, L., TU, C., HU, P., LIU, S., Influence of solid particle erosion (SPE) on safety and economy of steam turbines. Appl. Therm. Eng., 150, 2019, 552-563.

73.WANG, G., WANG, F., SHEN, F., JIANG, T., CHEN, Z., HU, P., Experimental and optical performances of a solar CPV device using a linear Fresnel reflector concentrator. Renew. Energy., 146, 2020, 2351-2361.

74.LEI, Z., JIHAO, C., ZHANG, L., HUIBIN, H., YUSU, W., YONGHUI, L., Preparation of soybean oil factory sludge catalyst and its application in selective catalytic oxidation denitration process. $J$. clean. Prod., 225, 2019, 220-226.

75.LEI, Z., YANG, J., HUIBIN, H., CHAO, Y., MIN, L., LINTIAN, M., Preparation of soybean oil factory sludge catalyst by plasma and the kinetics of selective catalytic oxidation denitrification reaction. J. clean. Prod., 217, 2019, 317-323.

76.ARRIZABALAGA, S., LI, Z., Factors Influencing the Assessment of Albacore Tuna Resources in the Indian Ocean. Ccamlr Sci., 25(2), 2018, 107-119.

77.BENNEMA, H., CORBETT, M., SMITH, C., Low-Cost, Annual Feeds: Comparison of Pen-Level Growth Performance in Uganda Native and Hybrid Pigs Fed Forage or Silage. Ccamlr Sci., 26(1), 2019, 78-84.

78.BOLTON, G., KOMATSU, H., First Japanese Record of the Barred Perchlet Plectranthias fourmanoiri. Ccamlr Sci., 26(1), 2019, 5-9.

79.BRAIN, B., STUART, J., Developing Somaclonal Variation of Bogor Taro to Expand the Diversity of Character. Ccamlr Sci., 26(1), 2019, 50-55.

80.BRIAN, M., Structure and Antioxidant Activity of Extracellular Polysaccharides from Antarctic Marine Filamentous Fungi. Ccamlr Sci., 25(1), 2018, 49-55.

81.CAMERON, L., ABDELKREIM, M., Estimation of Productivity for Acacia seyal (Delile) in Alazzazah Area. Ccamlr Sci., 25(4), 2018, 287-291.

82.COLliNS, G., FINLEY, G., LAHM, W., Trachylepis Keroanensis Rediscovered in West Africa. Ccamlr Sci., 25(4), 2018, 339-343.

83.COOPER, R., NEWMAN, P., HERACHWATI, N., RAPD Molecular Markers to Analyze the DNA Variation of the Three Bruguiera Species on Kemujan Island. Ccamlr Sci., 25(3), 2018, 209-214.

84.DAI, X. J., YIN, H., BAI, Y., Spatial and Temporal Variation Characteristics of Marine Wetland Ecological Environment Based on GIS. Ccamlr Sci., 25(3), 2018, 143-150.

85.INCE, C., DEROGAR, S., BALL, R. J., EKINCI, A., YUZER, N., Long-term mechanical properties of cellulose fibre-reinforced cement mortar with diatomite. Adv. Cem. Res., 31(8), 2019, 343-352.

$\overline{\text { Manuscript received: } 13.03 .2020}$ 